\title{
Aminated Polysaccharide Microspheres as DNA Delivery Systems
}

\author{
M. Constantin, G. Fundueanu, R. Cortesi, E. Esposito \& C. Nastruzzi
}

To cite this article: M. Constantin, G. Fundueanu, R. Cortesi, E. Esposito \& C. Nastruzzi (2003) Aminated Polysaccharide Microspheres as DNA Delivery Systems, Drug Delivery, 10:3, 138-149, DOI: $10.1080 / 713840403$

To link to this article: https://doi.org/10.1080/713840403

曲 Published online: 29 Sep 2008.

Submit your article to this journal ๘

Џll Article views: 112

Q View related articles $\asymp$

4 Citing articles: 2 View citing articles 준 


\title{
Aminated Polysaccharide Microspheres as DNA Delivery Systems
}

\author{
M. Constantin, G. Fundueanu, R. Cortesi, and E. Esposito \\ Department of Pharmaceutical Science, University of Ferrara, Ferrara, Italy \\ C. Nastruzzi \\ Department of Medicinal Chemistry and Pharmaceutics, University of Perugia, Perugia, Italy
}

\begin{abstract}
This article describes the production and characterization of cationic microparticles based on pullulan and starch for the delivery of nucleic acids. The microparticles were prepared by chemically cross-linkinking of a polymer solution dispersed in organic phase, followed by amination with $\mathrm{N}, \mathrm{N}$-diethyl-2-chloroethyl amine hydrochloride, or $\mathrm{N}$-glycidyl-N,N-dimethyl-N-methylammonium chloride. The association of desoxyribonucleotide (DNA) with positively charged microparticles was determined. The association capacity and the affinity of microspheres for DNA were investigated as a function of type of polysaccharide, content and basicity of the amino groups. It was found that the both types of carriers synthetized display a high affinity for defibrotide due to the high porosity of polysaccharide microspheres (PMs). The in vitro release kinetics from microspheres showed an initial fast release of DNA (30 $\mathrm{min}$ ) followed by slower release rate over 14 days. DNA release was influenced by the ionic strength of the receiving fluid. In addition, DNA release was slightly more rapid from pullulan than from starch complexes. DNA stability studies were performed by agarose gel, indicating no degradation even after 14 days. All the produced cationic microspheres were able to quantitatively load DNA. The release of DNA from PMs was strongly affected by the ionic strength of the receiving fluid. Finally, agarose gel electrophoresis of DNA released from microspheres indicated that no DNA degradation occurs even after 14 days of release from PMs.
\end{abstract}

Keywords Cationic Microparticles, Defibrotide, Pullulan, Starch

Received 5 June 2002; accepted 20 September 2002.

The authors are grateful to Dr. Franco Cervellati and the Electronic Microscopy Centre of the University of Ferrara, Ferrara, Italy. This work was supported by grants from the Italian Ministry of Foreign Affairs. Work supported by MIUR-COFIN-2002 (Application of diaelectrophoresis-based lab-on-a-chip to diagnosis and drug research and development).

Address correspondence to Prof. Claudio Nastruzzi, Dipartimento di Chimica e Tecnologia del Farmaco, Via del Liceo 1, I-06100 Perugia, Italy. E-mail: nas@unipg.it
Over the past 30 years, DNA delivery to in vitro cultured cells (i.e., transfection) has become a powerful and popular research tool for elucidating the structure, regulation, and function of genes. DNA delivery systems can be classified generally within two main classes: the viral mediated systems (e.g., adenoand retroviral vectors) (Curiel et al. 1992; Galanis, Vile, and Russell 2002; Kamiya et al. 2001) and the nonviral delivery systems (e.g., neutral or cationic liposomes and cationic polymers) (Spack and Sorgi 2001; Pouton and Seymour 2001; Ogris and Wagner 2002). Unfortunately, with respect to in vivo gene delivery, no definitive evidence has yet been presented for a clinical consistency of any gene therapy protocol.

The general failure of the current methodology is mainly due to limitations of viral systems, including toxicity, restricted targeting of specific cell types, limited DNA carrying capacity, packaging problems, and high production cost (Crystal 1995; Tripathy et al. 1996; Robbins, Tahara, and Ghivizzani 1998; Wu and Ataai 2000; Wilson 2001). The reason: nonviral systems, especially synthetic DNA delivery systems, have become increasingly desirable (Spack and Sorgi 2001; Pouton and Seymour 2001; Oku et al. 2001; Low 1995; Prokop et al. 2002).

An attractive class of nonviral transfection agents that has been considered is represented by cationic polymers. Their main advantage resides in the possibility to design and synthetize polymers carrying different structural elements that can selfassemble with DNA by electrostatic interactions to produce vectors with a range of properties. A number of "classic" cationic polymers (in form of colloidal dispersion) have been tested in transfection experiments such as DEAE-dextran (Vaheri and Pagano 1965), poly(L-lysine) (Curiel et al. 1992), polyethylenimine (Godbey et al. 1999), gelatin (Truong-Le, August, and Leong 1998), and more recently chitosan (Leong et al. 1998), methacrylate/methacrylamide polymers (Van de Wetering et al. 1999), poly(N-ethyl-4-vinylpyridinium bromide) (Kabanov and Kabanov 1995), and poly(2-(dimethylamino))ethyl methacrylate (Van de Wetering et al. 1998). 
Biocompatible controlled-release polymers also have been considered as synthetic DNA delivery systems such as poly(L-glutamic acid) (Dekie et al. 2000) and poly(D,L-lacticco-glycolic acid) (Tinsley-Bown et al. 2000). In particular, these polymers have been proposed for the production of microparticles. These formulations could offer some advantages with respect to other systems including the maintainance of their chemicophysical characteristics for long periods, the possibility to be administered through different ways depending on their composition and size (e.g., oral, intramuscular, or subcutaneous), and finally the suitability to industrial production.

From a theoretical point of view, microparticles could transport nucleic acids in two ways: by physical entrapment in the polymeric matrix of the microparticle or by electrostatic interactions occuring between the negatively charged DNA and the positively charged surface of the cationic microparticles. In particular, the second approach is based on the association of DNA molecules to preformed cationic microparticles or on the lyophilization of DNA in combination with the positively charge transfectant. These approaches provide the important benefit of not exposing nucleic acid molecules to chemical, thermal, and mechanical stresses often associated in the production of microparticles (Cortesi et al. 2000). In fact, gene transfer protocols for clinical uses would be based preferably on extemporaneously prepared formulations, assuring a better stability to the nucleic acid kept in the lyophilized form.

To develop new cationic polymeric microparticles made with natural biocompatible polysaccharides with good association capacity and high affinity for DNA, we considered chemically modified starch and pullulan for the production of cationic microparticles. In particular, cationized polymers allow us to avoid the use of blends of neutral polymers with cationic polymers or cationic surfactants that, due to their general toxicity, could cause cytotoxic effect if released from the microparticles (Soane et al. 1999).

This article describes the design and production of cationized microspheres based on pullulan and starch, together with their characterization in terms of shape and dimension, surface characteristics, DNA association behavior, and DNA release characteristic. The article ends by describing the in vitro short-term toxicity of the microparticles and their in vitro gene transfection ability.

\section{MATERIALS AND METHODS}

\section{Chemicals}

Pullulan $(\mathrm{Mw}=150.000 \mathrm{~g} / \mathrm{mol})$ was provided from Hayashibara Lab. LTD. (Okoyama, Japan). Starch (Mw = $80.000 \mathrm{~g} / \mathrm{mol}$ ) was kindly supplied by CERMAV (Grenoble, France). The molecular weight of the polymer were determined by size exclusion chromatography with differential viscometer and dual detection. N,N-diethyl-2-chloroethylamine hydrochloride and glycidyl trimethyl ammonium chloride were purchased from Fluka (Buchs, Switzerland).
As model DNA, defibrotide (DFT) (Esposito et al. 2002), a single stranded polydesoxyribonucleotide (DNA) sodium salt extracted from mammalian organs, was used (Crinos Industria Farmacobiologica S.p.A, Como, Italy). Toluene and 1,2dichloroethane were distilled prior the use. All the other reagents were purcheased from Fluka at the highest purity grade available.

\section{Production of Cross-Linked Pullulan and Starch Microspheres}

Cross-linked polysaccharides microspheres (PMs) were produced using a two-piece glass reactor (capacity $500 \mathrm{ml}$, vessel diameter $106 \mathrm{~mm}$, height $120 \mathrm{~mm}$ ) fitted with a lid (one center socket, 29/32; two angled side sockets, 19/26) and equipped with a mechanical stirrer with a three-blade turbine impeller (Eurostar Digital, Ika Labortechnick, Germany), condenser, and thermometer. The suspension medium was constituted of $80 \mathrm{ml}$ dichloroethane containing $2.5 \mathrm{~g}$ cellulose aceto butyrate (CAB), as dispersing agent. A solution containing $4 \mathrm{~g}$ of polymer (pullulan or starch) and $1.5 \mathrm{~g}$ of $\mathrm{NaOH}$ in $22 \mathrm{ml}$ water was placed into the flask heated at $50^{\circ} \mathrm{C}$ and stirred at $800 \mathrm{rpm}$. The obtained w/o emulsion was stirred for $1 \mathrm{hr}$ and after complete dispersion, $2 \mathrm{ml}$ of 1-chloro-2, 3-epoxypropane (ECP) were added. Afterward the cross-linking reaction was carried out for $8 \mathrm{hr}$ at $60^{\circ} \mathrm{C}$. The resulting microspheres were isolated by filtration and successively rinsed in the reactor with dichloroethane, acetone, deionized water, and ethanol $(50 \mathrm{ml} \times 2$ each $)$ and finally dried under vacuum at $50^{\circ} \mathrm{C}$ for $24 \mathrm{hr}$.

\section{Cationization of Polysaccharides Microspheres}

The synthetic scheme for the preparation of cationized polysaccharides with structure IV and V is depicted in Figure 1. The functional cationic side chains were introduced as follows. For type IV microspheres, $0.5 \mathrm{~g}$ of the cross-linked pullulan microspheres, corresponding to 3.08 m equivalents of glucopyranoside unit (GU), were swollen in $8 \mathrm{ml}$ of an aqueous solution containing $0.8 \mathrm{~g} \mathrm{NaOH}$ and $5 \mathrm{mg} \mathrm{NaBH}$. The swollen microspheres were then dispersed in $10 \mathrm{ml}$ of 1,2-dichloroethane and $1.59 \mathrm{~g}$ $(9.26 \mathrm{mmol})$ of $\mathrm{N}, \mathrm{N}$-diethyl-2-chloroethylamine hydrochloride, dissolved in $2 \mathrm{ml}$ of water, and added to the suspension. The mixture was left to react for $6 \mathrm{hr}$ under stirring at $70^{\circ} \mathrm{C}$. After cooling at room temperature, the microspheres were filtered and consecutively rinsed on the filter with water, a $0.1 \mathrm{~N} \mathrm{HCl}$ solution, water, methanol, and finally acetone.

For type $\mathrm{V}$ microspheres, $0.5 \mathrm{~g}$ of the cross-linked pullulan microspheres, corresponding to 3.08 mequivalents $\mathrm{GU}$ were swollen in $4 \mathrm{ml}$ of an aqueous solution containing $0.4 \mathrm{~g} \mathrm{NaOH}$ and $5 \mathrm{mg} \mathrm{NaBH} 4$. Thereafter, $6 \mathrm{ml}$ of 1,2-dichloroethane were added and $1.4 \mathrm{~g}(9.25 \mathrm{mmol})$ of N-glycidyl-N,N-dimethyl-Nmethylammonium chloride, dissolved in $2 \mathrm{ml}$ of water, were added to the suspension. The mixture was left to react for 6 $\mathrm{hr}$ under stirring at $70^{\circ} \mathrm{C}$. After cooling at room temperature, the microspheres were treated as described for type IV microspheres. The aminated type IV and type V starch microspheres 


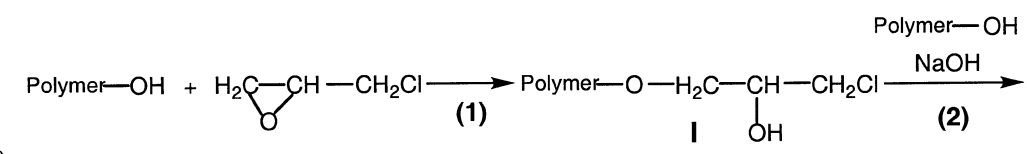

a)
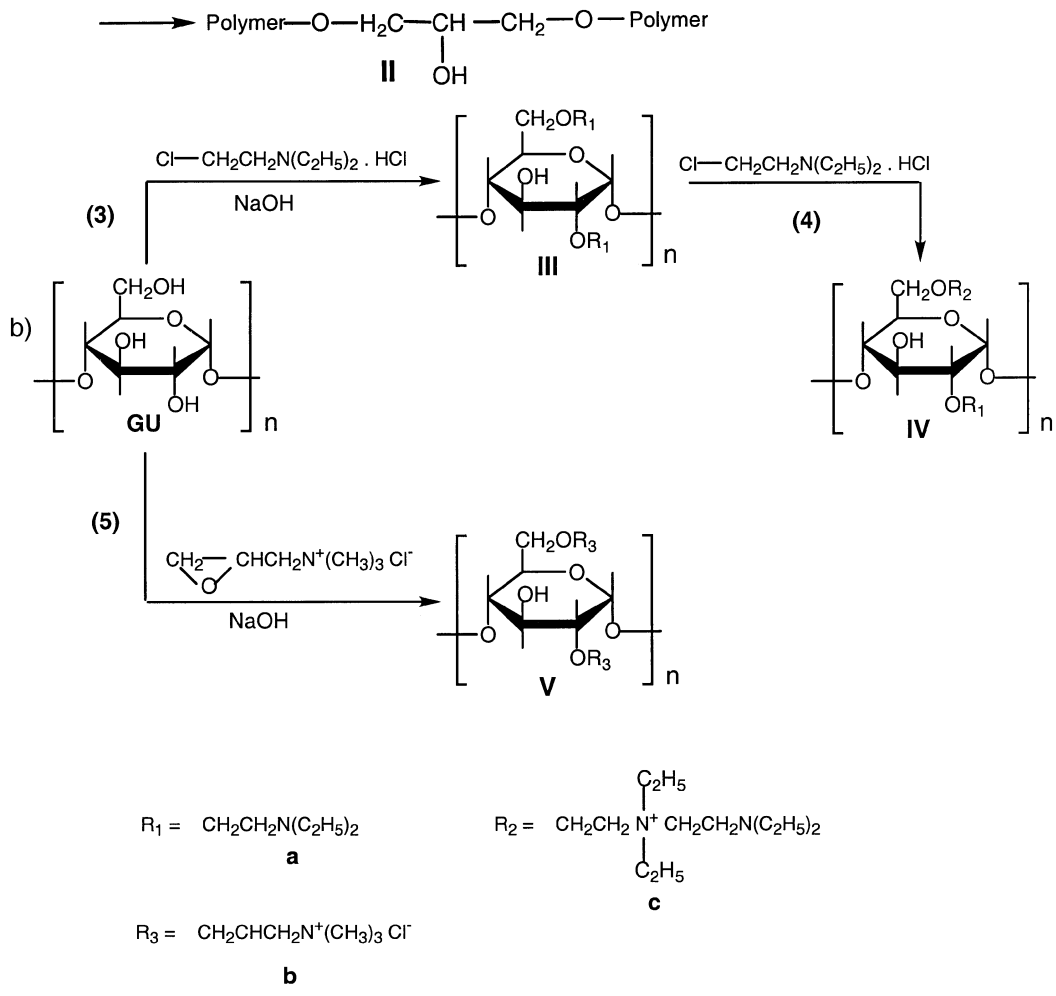

FIG. 1. Preparation of cross-linked and aminated polysaccharide microspheres.

were obtained using the same procedure with the exception that no suspension medium (1,2-dichloroethane) was used.

\section{Microsphere Characterization}

Microparticle morphology, size, and size distributions were determined by optical and electron microscopy observations considering at least 250 microparticles. For the optical analysis, an optical microscope Diaphot (Nikon, Japan) was employed. For the electronical analysis, microparticles were metallized by gold coating (Edwards Sputter coating S150) and analyzed at 15-20 Kv by a scanning electron microscope (SEM) 360 Stereoscan (Cambridge Instruments, Cambridge, U.K.).

The swelling characteristics of microparticles were determined in hydrophilic gel prepared by solubilizing poloxamer $407(20 \%, \mathrm{w} / \mathrm{v})$ in water at $0^{\circ} \mathrm{C}$ (Cortesi et al. 1999). The kinetics of the increase of the initial diameter of particles was performed at $37^{\circ} \mathrm{C}$ using an optical microscope equipped with a micrometric device considering at least 200 particles/sample. The swelling ratio $q$ was calculated according by the following equation measuring the diameter of gelatin microsphere, assuming for particles a spherical geometry.

$$
q=\frac{V_{s}}{V_{d}}
$$

where $V_{s}$ and $V_{d}$ are the volume of the swollen microspheres and of the dried microspheres, respectively.

\section{Determination of Microspheres Exchange Capacity}

The anion exchange capacity of cationized PMs was determined under dynamic conditions by standard methods (Helfferich 1962) and expressed as meq amino groups/g dry microspheres. Briefly, $50 \mathrm{mg}$ of cationic microspheres were suspended in $50 \mathrm{ml}$ deionized water; after swelling, the microparticles were quantitatively transferred into a glass column $(20 \times 60 \mathrm{~mm})$. A $0.1 \mathrm{~N} \mathrm{NaOH}$ solution $(50 \mathrm{ml})$ was passed through the column and the microspheres, in the $-\mathrm{OH}$ form, were washed with water until neutrality of the collected eluate. Thereafter, $50 \mathrm{ml} \mathrm{5 \%} \mathrm{NaCl}$ solution and $50 \mathrm{ml}$ water were successively passed on the microsphere bed and the collected eluate was titrated with a $0.1 \mathrm{~N} \mathrm{HCl}$ solution.

The content of quaternary ammonium groups was calculated using the following equation:

$$
\mathrm{EC}(\mathrm{meq} / \mathrm{g})=\left[\left(\mathrm{n}_{\mathrm{HCl}} \times \mathrm{f}_{\mathrm{HCl}}\right) / \mathrm{a}\right] \times 0.1
$$

Where EC is the exchange capacity, $\mathrm{n}_{\mathrm{HCl}}$ and $\mathrm{f}_{\mathrm{HCl}}$ are the volume (ml) and the concentration of $\mathrm{HCl}$ solution used, respectively, for titration, and $a$ is the weight of the microparticles. 
To determine the content of tertiary amino groups, $50 \mathrm{ml} 0.1 \mathrm{~N}$ $\mathrm{HCl}$ solution, $50 \mathrm{ml}$ water, and $50 \mathrm{ml}$ methanol were successively passed through the column, and the eluate collected was titrated with a $0.1 \mathrm{~N} \mathrm{NaOH}$ solution. The exchange capacity was calculated as follows:

$$
\mathrm{EC}(\mathrm{meq} / \mathrm{g})=\left[\left(\mathrm{n}_{\mathrm{HCl}} \times \mathrm{f}_{\mathrm{HCl}}-\mathrm{n}_{\mathrm{NaOH}} \times \mathrm{f}_{\mathrm{NaOH}}\right) / \mathrm{a}\right] \times 0.1
$$

Where $\mathrm{n}_{\mathrm{HCl}}$ and $\mathrm{f}_{\mathrm{HCl}}$, respectively, are the volume $(\mathrm{ml})$ and concentration of $\mathrm{HCl}$ solution used and $\mathrm{n}_{\mathrm{NaOH}}$ and $\mathrm{f}_{\mathrm{NaOH}}$ the volume (ml) and concentration of $\mathrm{NaOH}$ solution used for the titration; $a$ is the weight of the polymeric microparticles.

\section{DNA-Binding Capacity of Cationic Microspheres}

Cationic microspheres were suspended in $3 \mathrm{ml}$ of an aqueous solution containing $250 \mu \mathrm{g} / \mathrm{ml}$ of DNA. The suspension was maintained under mixing for $3 \mathrm{hr}$ using an orbital Ika stirring motor (Labortechnik K Mot, Germany) set at $150 \mathrm{rpm}$. The amount of associated DNA was calculated evaluating the concentration of free DNA in water after filtration of the microspheres. DNA determination was performed by ultraviolet spectrophotometric analysis (Perkin, Elmer, Norwalk, CT, USA), using a previously constructed calibration curve (Esposito et al. 1999; Cortesi et al. 2000).

\section{DNA Association Kinetics}

Cationic microparticles were suspended in $3 \mathrm{ml}$ of an aqueous solution containing $250 \mu \mathrm{g} / \mathrm{ml}$ of DNA and maintained under stirring at room temperature. The suspensions were filtered at given time intervals and then the filtrates were analyzed by ultraviolet for DNA content.

\section{Release Kinetics of DNA from Cationic Microspheres}

Fully $20 \mathrm{mg}$ of DNA-loaded microspheres were suspended in $20 \mathrm{ml}$ of phosphate buffer $(\mathrm{pH}=7.4)$ containing $0.25 \mathrm{M}, 0.5$ $\mathrm{M}$, or $1 \mathrm{M} \mathrm{NaCl}$. The resulting suspension was placed in sealed vials under shaking at $150 \mathrm{rpm}$. Periodically, $5 \mathrm{ml}$ of the release medium were pipetted out from the vials and the same volume of fresh medium was replaced; the release medium was analyzed for DNA content by ultraviolet spectroscopic analysis.

\section{Stability of DNA}

The stability of DNA after release from microspheres was investigated by agarose gel electrophoresis. DNA electrophoresis was performed in $3 \%(\mathrm{w} / \mathrm{v})$ agarose gels containing $0.5 \mu \mathrm{m}$ ethidium bromide for visualization, for $3 \mathrm{hr}$ at $25 \mathrm{mV}$ constant current. The relative band migration was determined, after staining the gels with ethidium bromide.

\section{Cytotoxic Activity of Cationic Microspheres}

Cytotoxicity of cationic microspheres was evaluated on human leukemic K562 (S) cells. Standard conditions for cell growth were $\alpha$-medium (GIBCO, Grand Island, NY, USA), $50 \mathrm{mg} / \mathrm{l}$ streptomycin, $300 \mathrm{mg} / \mathrm{l}$ penicillin supplemented with $10-15 \%$ fetal calf serum (Flow Laboratories, McLean, VA, USA) in 5\% $\mathrm{CO}_{2}, 80 \%$ humidity.

Human leukemic K562(S) cells were treated with different amount of cationic microspheres (espressed as molar amount of cationic groups present on the microparticles). After 6 days of cell culture, the cells were counted by a cell counter Fuchs (Tosenthal, Preciss, France) and the number of cells/ml was compared with the value obtained in untreated cell cultures to determine the percentage of surviving cells. Assays were carried out in triplicate and usually counts differed by $<7 \%$.

\section{RESULTS AND DISCUSSION}

\section{Rational of Polysaccharide Microsphere}

The PMs for gene medicines (nucleic acid based drugs) described here could be suitably administered through different ways with respect to the type of pharmacological action required (i.e., local vs. systemic or target tissue to be reached). Microspheres could be administered through the classical parenteral ways (e.g., intramuscular or subcutaneous injections) or alternatively through an embolization procedure to selectively target specific organs as in antitumoral therapies. In addition, the PMs could find an interesting therapeutic application for the delivery of nucleic acid based drugs to the skin and through mucosal tissues (nasal, oral, and vaginal) (Lindberg, Lote, and Teder 1984; Teder and Johanssan 1993; Illum et al. 1984; Hamdi, Ponchel, and Duchene 1998).

With respect to transmucosal absorption, starch microspheres, due to their large water absorption, can dehydrate the epithelial mucosa causing a reversible shrinkage of the epithelial cells. This shrinkage could lead to the physical separation of the intracellular junctions and thus enhance paracellular absorption. This hypothesis was supported by a study that reported focal dilations in the tight junctions between human intestinal epithelial Caco- 2 cells after administration of starch microspheres (Bjork et al. 1995).

It should be emphasized that the polysaccharide microspheres described here transport the nucleic acid molecules through electrostatic interactions occurring between the negatively charged nucleic acid molecules and the positively charged surface of the cationic starch or pullulan microspheres.

\section{Preparation and Characterization of Polysaccharide Microspheres}

PMs were produced by a suspension cross-linking procedure with 1-chloro-2,3-epoxy-propane (Figure 1, panel A). The reaction was carried out in a water/organic solvent suspension using a $18 \%(\mathrm{w} / \mathrm{w})$ aqueous polymer solution (Table 1$)$.

The produced PMs are characterized, as evidenced by electron microscopy (SEM analysis in Figure 2), by a good spherical geometry and a smooth surface. The starch microspheres display a porous internal structure (Figure 2B), whereas the pullulan ones show an internal cavity (Figure 2D). Both types of microspheres are typified by a relative narrow size distribution 
TABLE 1

General characteristics of cross-linked polysaccharide microspheres

\begin{tabular}{lccccc}
\hline Sample & $\begin{array}{c}\text { Polymer } \\
\text { support }\end{array}$ & $\begin{array}{c}\text { Polymer } \\
\text { concentration } \\
(\%, w / v)\end{array}$ & $\begin{array}{c}\text { Cross-linking } \\
\text { degree } \\
(\text { mol ECH/UG })\end{array}$ & $\begin{array}{c}\text { Swelling } \\
\text { degree in } \\
\text { water }(\mathrm{q})\end{array}$ & $\begin{array}{c}\text { Mean } \\
\text { diameter } \\
(\mu \mathrm{m})\end{array}$ \\
\hline P\#1 & Pullulan & 18 & $1.03 / 1$ & $6.4 \pm 0.8$ & $163 \pm 15$ \\
S\#1 & Starch & 18 & $1.03 / 1$ & $5.2 \pm 0.7$ & $85 \pm 13$ \\
\hline
\end{tabular}

${ }^{*} \mathrm{q}=\mathrm{Vs} / \mathrm{Vd}$ (swollen volume/dried volume). Data represent the mean of four independent microsphere batches \pm SD.

with a mean diameter of $85 \mu \mathrm{m}$ and $160 \mu \mathrm{m}$, for starch and pullulan microspheres, respectively, as evidenced by the cumulative frequency distribution plots depicted in Figure 3A and 3B and Table 1.

After preparation, cross-linked PMs were treated with $\mathrm{N}, \mathrm{N}-$ diethyl-N-(2-chloroethyl)amine (Figure 1, panel B). During the amination of polysaccharide microspheres, two successive reactions occur, namely the etherification of the hydroxyl groups of the polysaccharide moyety (reaction 3 ) and the quaternarization of the newly introduced amino group (reaction 4). In this way, the resulting derivatized microspheres possess three types of basic groups with different $\mathrm{pK}_{\mathrm{b}}$ : two groups of moderate basicity (Figure 1, panel B, structure III, IV) and a strong quaternary amonium basic group (Figure 1, panel B, structure IV).
On the contrary, the derivatization of cross-linked PMs with glycidyltrialkyl ammonium chloride (Figure 1, reaction 5) gave rise to microspheres containing only quaternary ammonium groups (structure V). To obtain cationic microspheres with different content of amino groups, the amination reaction was conducted employing different molar ratios between reactant and (GU), namely amine/GU and $\mathrm{NaOH} / \mathrm{GU}$ (see Table 2). The SEM analysis of the cationized microspheres showed that these particles have a more irregular surface with respect to the initial crosslinked neutral PMs (Figure 4A-4C), but no significant changes in the particle mean diameter were observed (Tables 2 and 3). The determination of DNA-loading capacity was performed using different cationized microparticles, whose characteristics are reported in Tables 2 and 3.

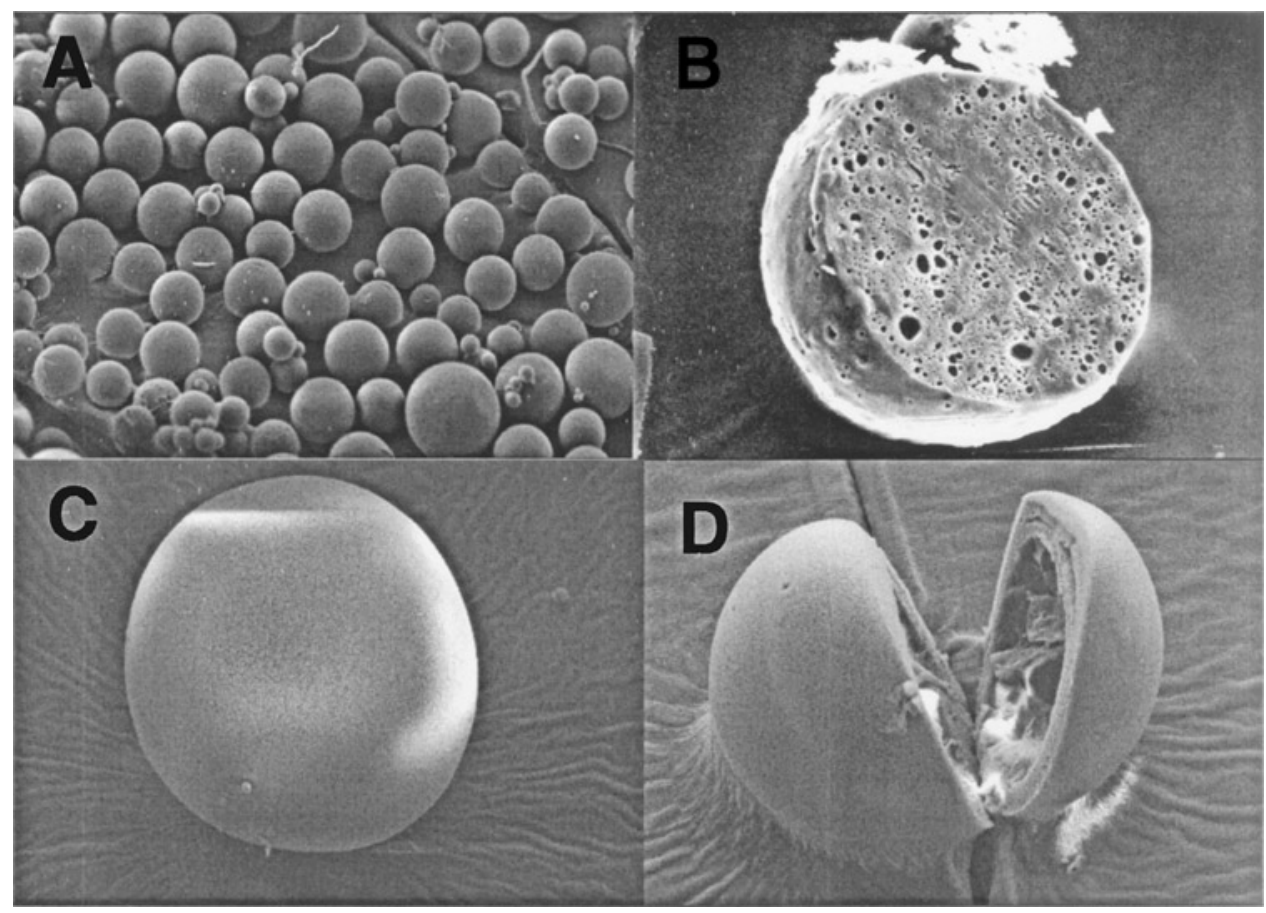

FIG. 2. Scanning electron photographs of polysaccharide microspheres. General view and cross-section of starch (A, B) and pullulan (C, D) microspheres. Bar corresponds to $260,55,95$, and $100 \mu \mathrm{m}$ in panels A, B, C, and D, respectively. 

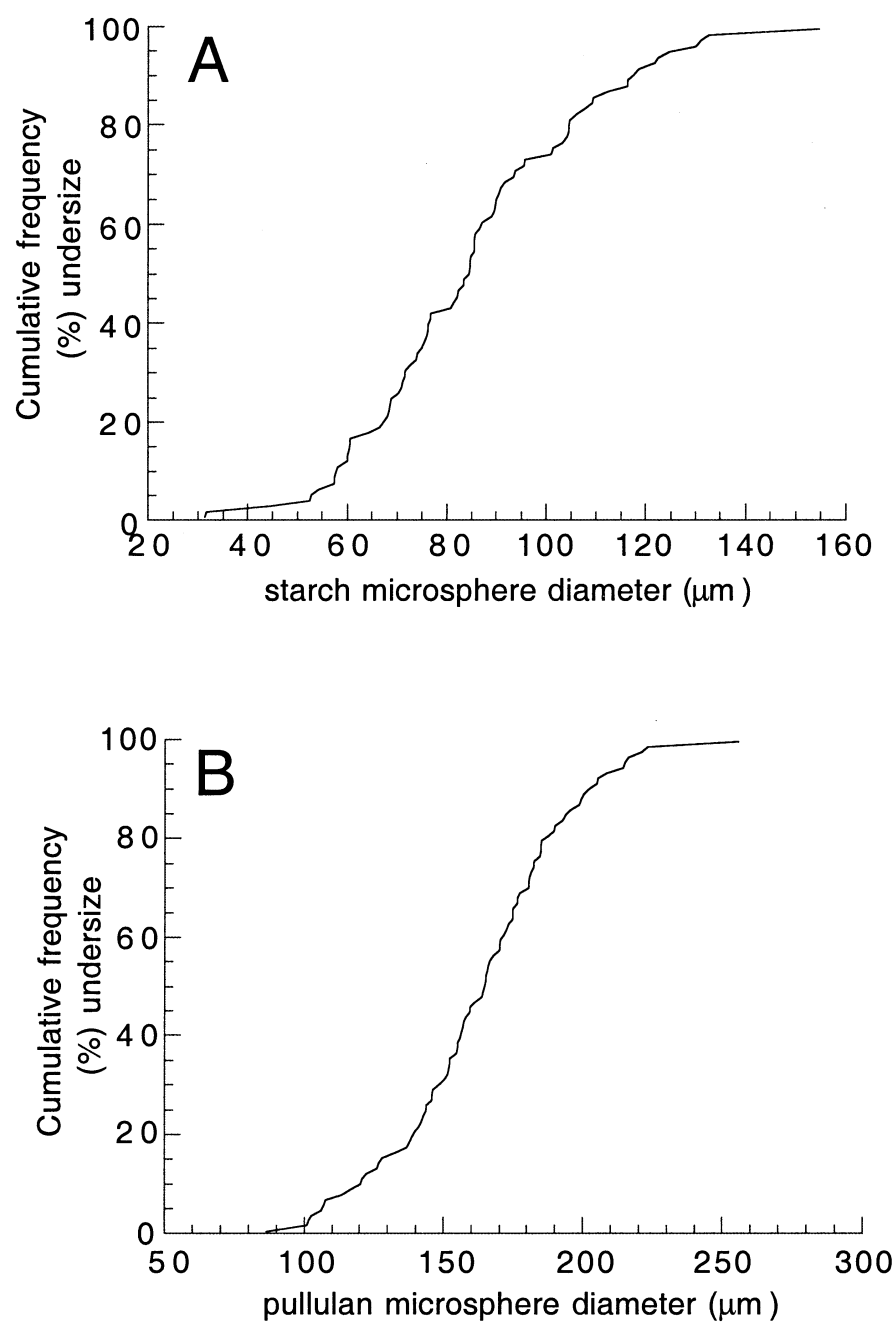

FIG. 3. Cumulative size distribution analysis of starch and pullulan microspheres. A = sample S\#1. B = sample P\#1. Data represent the mean of four independent microsphere batches.

\section{In Vitro Association of DNA}

To evaluate the ability of cationic microspheres to ionically complex and to transport nucleic acids, a series of binding experiments were performed using as model nucleic acid molecule, defibrotide (DFT), a single-stranded polydesoxyribonucleotide (DNA) with Mw of 26,200 daltons. The DFT sequence contains aptamers able to bind thrombin or possibly other proteins. DFT possesses a wide pharmacological profile, including profibrinolytic, anthrombotic-thrombolytic, and anti-ischemic activities (Esposito et al. 2002). DFT containing pharmaceutical formulations are commercially available for both parenteral and oral administration.

Typically, cationic PMs were suspended in deionized water containing DNA, at different molar ratios (from 0.25:1 to $8: 1,+/-)$ between the positive charges present on the cationic microspheres and the negative charges. Figure 5 illustrates the ability of cationic pullulan (Figure 5A) and starch (Figure 5B) microspheres (both with structures IV) to bind DNA.

The results show that both type of cationic microspheres are able to efficiently load DNA. In fact, about $50 \%$ of DNA is bound at a molar charge ratio of $0.5: 1(+/-)$ and over $80 \%$ at $1: 1$ $(+/-)$. Similarly, the association of DNA to microspheres with structure V (see Figure 1) depicted in Figures 5C and 5D is very high, being almost quantitative at $1: 1(+/-)$ molar charge ratio. As expected, an increase in the proportion of positive charges of microspheres (obtained by increasing the content of amino groups of the polymer) led to a progressive increase in the association of DNA to the carrier.

Figure 6 shows the association kinetics for the different cationic microspheres using a fixed 1:1 ratio between positive and negative charges. These experiments clearly indicate that all cationic particles present a very strong ability to rapidly bind DNA; in fact, after $5 \mathrm{~min}$, the percentages of association were between $40 \%$ for type IV microspheres (Figure 6A) and 76\% for type $\mathrm{V}$ microspheres (Figure 6C). In particular, cationic PMs with structure $\mathrm{V}$ (Figure 6C and 6D) showed a faster association kinetic because of the presence of the strongly basic quaternary amino groups.

\section{Release Kinetics of DNA from Cationic Microspheres}

The determinations of the release kinetics of DNA from cationic microspheres were performed in static conditions using as release medium phosphate buffer ( $\mathrm{pH}$ 7.4) or saline phosphate buffer of different ionic strengths (from 0.25 to $1 \mathrm{M}$ ). The

TABLE 2

Preparation conditions* and final characteristics of aminated polysaccharides microspheres with structure IV**

\begin{tabular}{|c|c|c|c|c|c|c|c|}
\hline Sample & $\begin{array}{c}\text { Polymer } \\
\text { support }\end{array}$ & Solvent & $\begin{array}{c}\text { Molar ratio } \\
\text { amine/UG }\end{array}$ & $\begin{array}{c}\text { Molar } \\
\text { ratio } \\
\mathrm{NaOH} / \mathrm{UG}\end{array}$ & $\begin{array}{c}\text { Exchange } \\
\text { capacity } \\
(\mathrm{meq} / \mathrm{g})\end{array}$ & $\begin{array}{l}\text { Swelling } \\
\text { degree } \\
\text { (q) }\end{array}$ & $\begin{array}{c}\text { Mean } \\
\text { diameter } \\
(\mu \mathrm{m})\end{array}$ \\
\hline$\overline{\mathrm{PCl} \# 1}$ & Pullulan & DCE & $6 / 1$ & $2 / 1$ & 1.1 & $8.4 \pm 0.9$ & $172 \pm 18$ \\
\hline $\mathrm{PCl} \# 2$ & & DCE & $3 / 1$ & $2 / 1$ & 2.1 & $10.2 \pm 1.1$ & $153 \pm 14$ \\
\hline $\mathrm{SCl} \# 1$ & Starch & Water & $3 / 1$ & $1 / 1$ & 1.01 & $6.5 \pm 0.3$ & \\
\hline $\mathrm{SCl} \# 2$ & & Water & $3 / 1$ & $1 / 1$ & 1.8 & $7.8 \pm 0.6$ & $81 \pm 10$ \\
\hline
\end{tabular}

${ }^{*}$ All reactions were performed for $6 \mathrm{hr}$ at $70^{\circ} \mathrm{C}$ (except SCl\# 1 prepared at $60^{\circ} \mathrm{C}$ ).

** See Figure 1.

Data represent the mean of four independent microsphere batches \pm SD. 


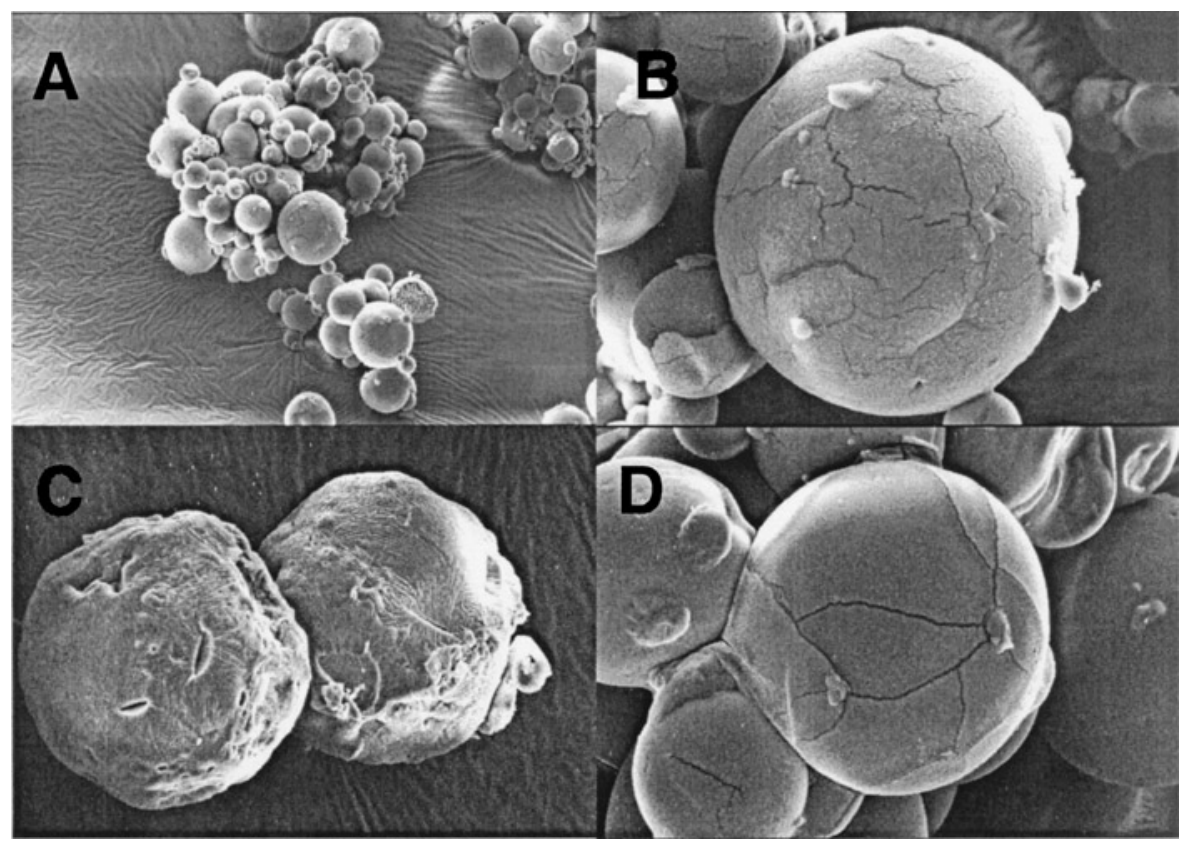

FIG. 4. Scanning electron photographs of cationized polysaccharide microspheres. The following type of microspheres were depicted: cationized starch type IV (A, B), cationized pullulan type IV (C), and cationized starch type V (D) microspheres. Bar corresponds to 405, 50, 113, and $110 \mu \mathrm{m}$ in panels A, B, C and D, respectively.
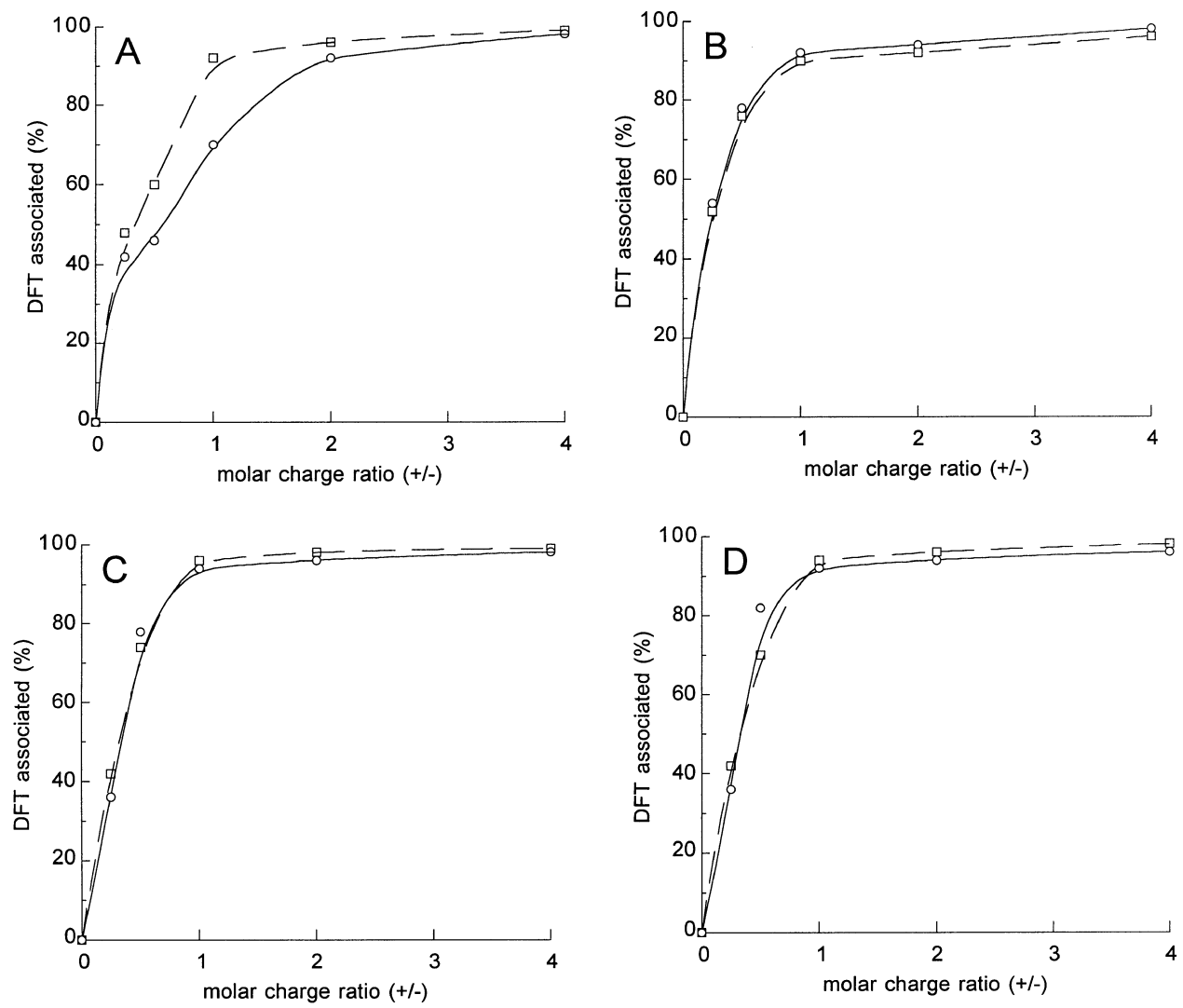

FIG. 5. DNA-loading ability of cationic pullulan (A: PCl\#1-O; PCl\#2- $\square$ ) and starch (B: SCl\#1-O; SCl\#2- $\square$ ) microspheres with structure IV; pullulan (C: PG\#1-O; PG\#2- $\square$ ) and starch (D: SG\#1-O; SG\#2- $\square$ ) with structure V. Data represent the mean of four independent microsphere batches. 
TABLE 3

Preparation conditions* and final characteristics of aminated polysaccharides microspheres with structure $\mathrm{V}^{* *}$

\begin{tabular}{lccccccc}
\hline $\begin{array}{c}\text { Polymer } \\
\text { support }\end{array}$ & Sample & Solvent & $\begin{array}{c}\text { Molar ratio } \\
\text { amine/UG }\end{array}$ & $\begin{array}{c}\text { Molar } \\
\text { ratio } \\
\text { NaOH/UG }\end{array}$ & $\begin{array}{c}\text { Exchange } \\
\text { capacity } \\
(\mathrm{meq} / \mathrm{g})\end{array}$ & $\begin{array}{c}\text { Swelling } \\
\text { degree } \\
(\mathrm{q})\end{array}$ & $\begin{array}{c}\text { Mean } \\
\text { diameter } \\
(\mu \mathrm{m})\end{array}$ \\
\hline Pullulan & PG\# 1 & DCE & $3 / 1$ & $1 / 1$ & 0.85 & $8.4 \pm 0.7$ & $104 \pm 12$ \\
& PG\# 2 & DCE & $8 / 1$ & $1 / 1$ & 2.1 & $11 \pm 0.9$ & \\
Starch & SG\# 1 & Water & $3 / 1$ & $1 / 1$ & 1 & $6.8 \pm 0.3$ & $82 \pm 8$ \\
& SG\# 2 & Water & $6 / 1$ & $0.33 / 1$ & 2.1 & $8.2 \pm 0.5$ & $82 \pm 10$ \\
\hline
\end{tabular}

${ }^{*}$ All reactions were performed for $6 \mathrm{hrs}$ at $70^{\circ} \mathrm{C}$.

${ }^{* *}$ See Figure 1.

DNA-microsphere complexes were obtained using $250 \mu \mathrm{g} / \mathrm{ml}$ of DNA and the microspheres at 1:1 (+/-) charge ratio. The complexes were allowed to self-assemble in water for $24 \mathrm{hr}$. Loaded microspheres were then filtered and dried at room temperature before use.

Figure 7A shows the in vitro DNA release profiles from the PMs with structure $\mathrm{V}$ at loading level of $40 \%$ (w/w) in phosphate buffer (pH 7.4). For both kinds of polymers, about $3 \%$ of DNA was available for a relatively fast release during $30 \mathrm{~min}$ and another $7 \%$ was then released at a slower rate over 14 days. The initial fast release phase could be due to the fraction of more loosely DNA complexed to the surface of the microparticles.

The data reported in Figure 7B and 7C show that the DNA release from microspheres was dramatically affected by the ionic strength of the receiving fluid. In particular, $37 \%$ of DNA was released when the molarity of release medium is $0.25 \mathrm{M}, 80 \%$
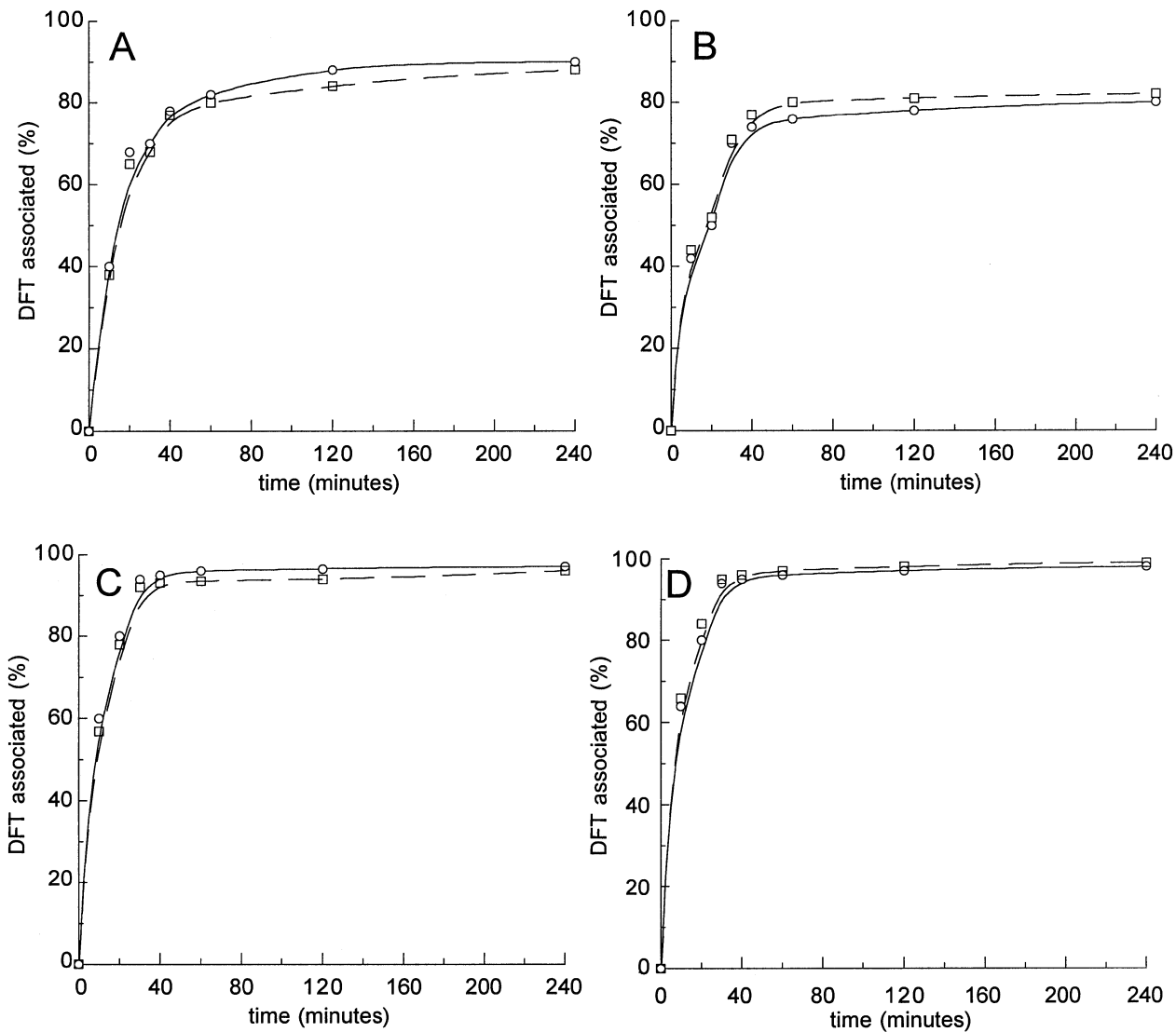

FIG. 6. Association kinetics of DNA to cationic polysaccharides microspheres: pullulan (A: PCl\#1-O; PCl\#2- $\square$ ) and starch (B: SCl\#1-O; SCl\#2- $\square$ ) microspheres with structure IV; pullulan (C: PG\#1-O; PG\#2- $\square$ ) and starch (D: SG\#1-O; SG\#2- $\square$ ) with structure V. Data represent the mean of four independent microsphere batches. 

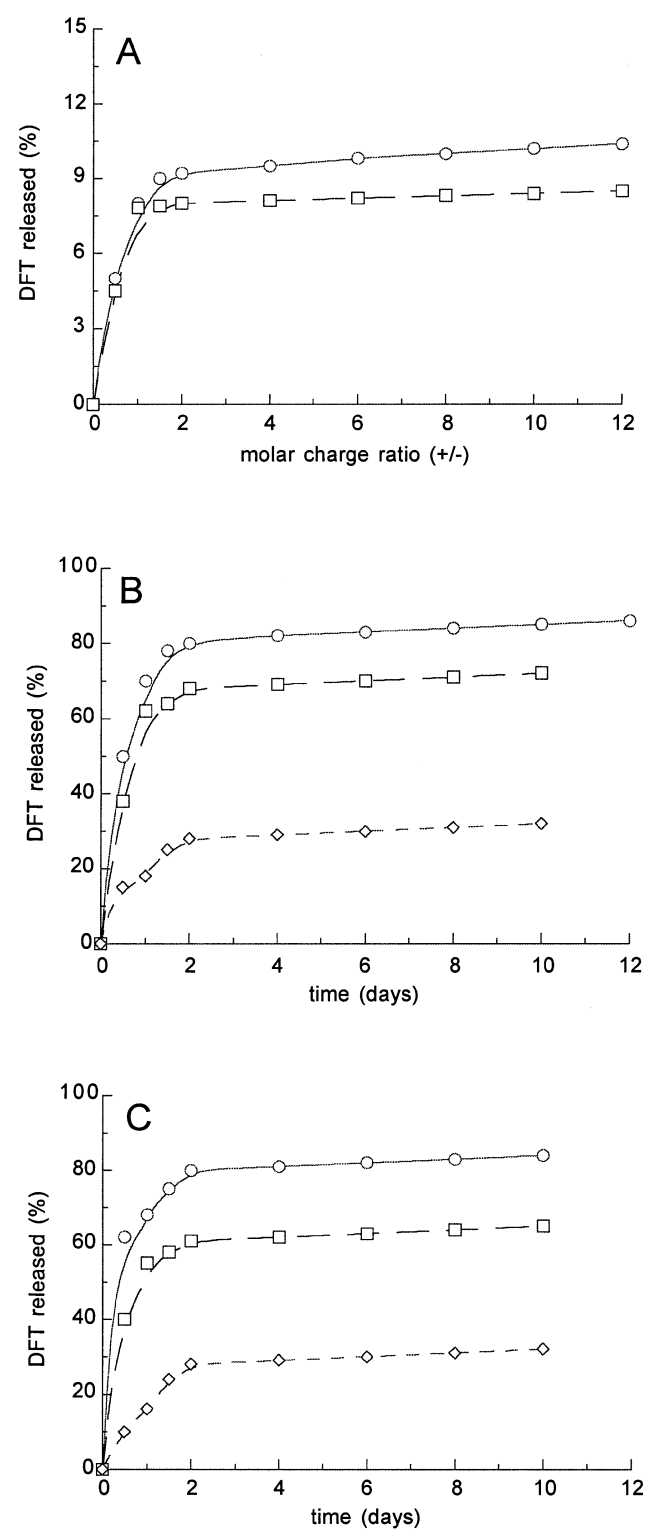

FIG. 7. A. Release profiles of DNA at a loading level of $40 \%$ (w/w), from cationic polysaccharides microspheres with structure $\mathrm{V}$ in isotonic phosphate buffer (pH 7.4); PG\#1-O; SG\#1- $\square$ ). B. Effect of receiving fluid ionic strength on the release of DNA from cationic pullulan microspheres (PG\#1) at a loading level of $40 \%(\mathrm{w} / \mathrm{w})$ : $1 \mathrm{M}(\mathrm{O}), 0.5 \mathrm{M}(\square)$, and $0.25 \mathrm{M}(\diamond)$. C. Effect of receiving fluid ionic strength on the release of DNA from cationic starch microspheres (SG\#1) at a loading level of $40 \%(\mathrm{w} / \mathrm{w}): 1 \mathrm{M}(\mathrm{O}), 0.5 \mathrm{M}(\square)$, and $0.25 \mathrm{M}(\diamond)$. Data represent the mean of four independent microsphere batches.

of DNA was released in a $0.5 \mathrm{M}$ release medium, and $90 \%$ when $\mathrm{NaCl}$ concentration is $1 \mathrm{M}$.

We observed that at the same loading level of DNA, the release is slightly more rapid from the pullulan complexes than from the starch complexes (Figure 7A). This behavior could be related to the different internal structures of the microspheres. SEM analysis of pullulan microspheres recovered after DNA

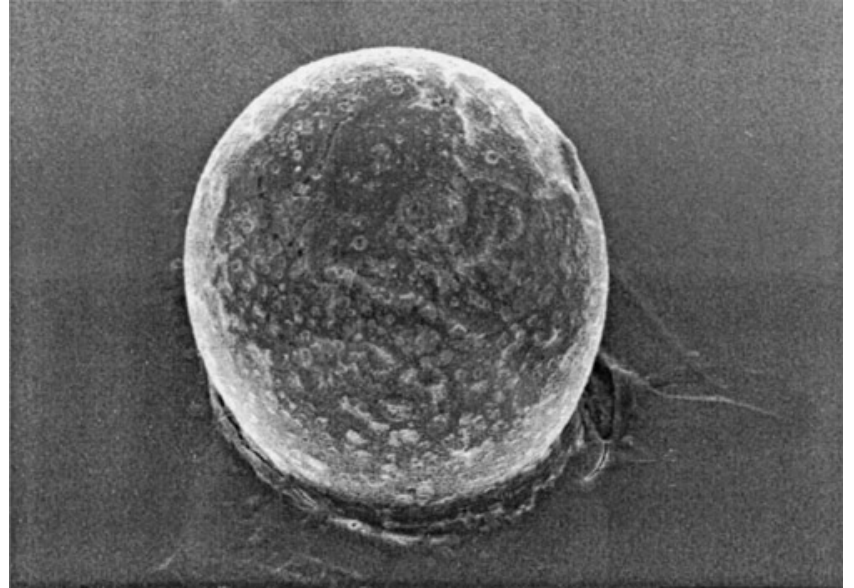

FIG. 8. Scanning electron photograph of pullulan microspheres with structure $\mathrm{V}$ after release of DNA for 12 days in $1 \mathrm{M} \mathrm{NaCl}$ in phosphate buffer; bar corresponds to $54.6 \mu \mathrm{m}$.

release (in $1 \mathrm{M} \mathrm{NaCl}$ release medium) evidenced no substantial changes in the morphology of microspheres (Figure 8).

\section{DNA Stability}

The stability of DNA after association and release from cationic micropheres was evaluated by agarose gel electrophoresis of the released DNA. Figure 9 shows agarose gel electrophoresis of DNA-containing fractions collected after $8 \mathrm{hr}, 2,6,10$, and 14 days of release in a $0.5 \mathrm{M} \mathrm{NaCl}$ (Figure $9 \mathrm{~A}$ ); or in $1 \mathrm{M} \mathrm{NaCl}$ release medium (Figure 9B). In all cases the migration of DNA resulted in a single band similar to that of control indicating that no DNA degradation occurs even after 14 days of release from microspheres.

\section{In Vitro Toxicity of Cationized PMs}

To obtain information about the cytotoxicity of cationic microspheres, in vitro assays were performed by cultivating human leukemic $\mathrm{K} 562(\mathrm{~S})$ cells in the presence of microspheres. Increasing concentrations of cationic microspheres, having $\sim 1 \mathrm{meq} / \mathrm{g}$ amino groups content, were added to the cells.

The results, reported in Figure 10, indicate that the both starch and pullulan microspheres (with type IV and V structure, see Figure 1) showed a moderate cytotoxic effect. The $\mathrm{IC}_{50}$ values (expressed as molar concentration of cationic groups present on the microparticles) were $62.5 \mu \mathrm{M}$ for starch microspheres and $250 \mu \mathrm{M}$ for the pullulan ones $\left(\mathrm{IC}_{50}\right.$ is the compound concentration inhibiting $50 \%$ of the cell growth). The obtained results demonstrated that no appreciable difference in the cytotoxic activity was observed. Nevertheless, in cationic starch microspheres, one could observe a slightly increased cytotoxicity; this fact can be due to the higher content in amino groups of starch microspheres used in the experiment. 

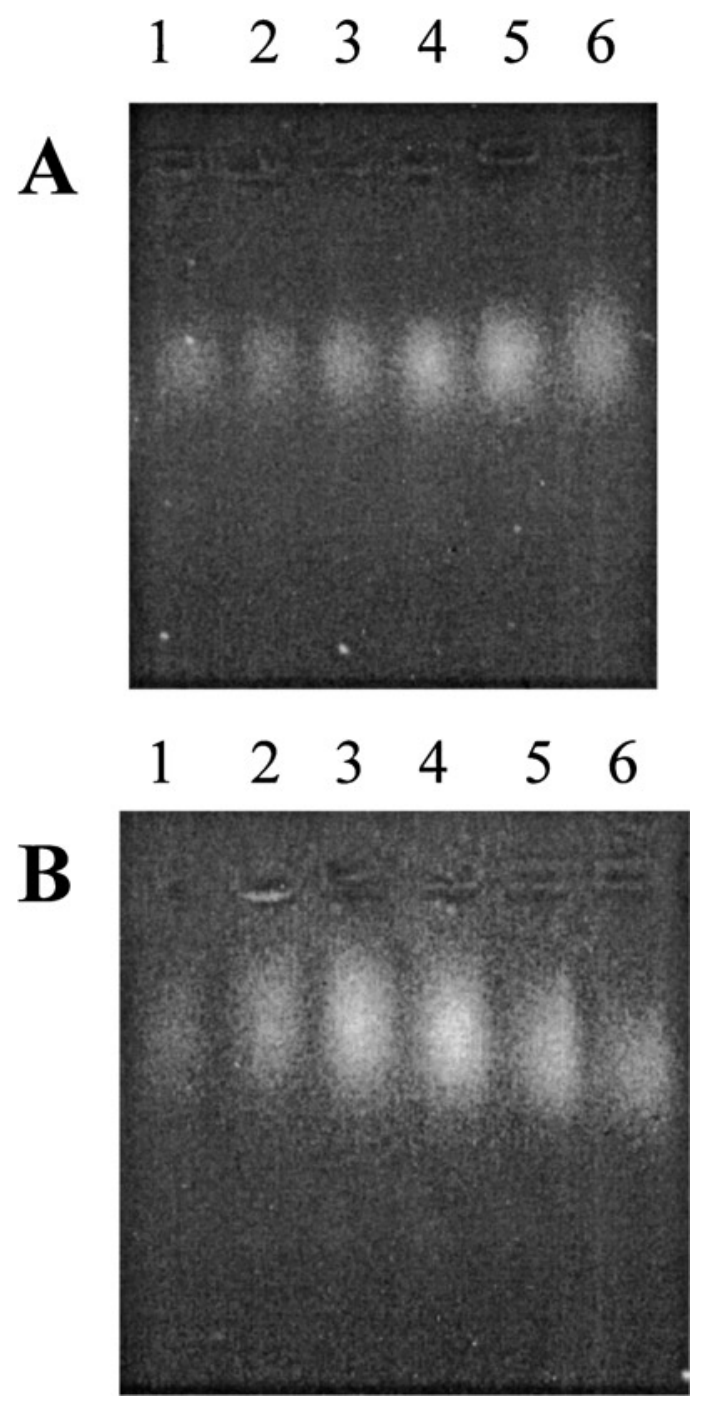

FIG. 9. Agarose gel electrophoresis of DFT-containing fractions collected during release experiments from pullulan microspheres with structure IV. (A) Analysis of DFT released from microspheres in $0.5 \mathrm{M} \mathrm{NaCl}$ in phosphate buffer, at various time points: Lanes 1-5: DFT in fractions collected at $8 \mathrm{hr}, 2,6,10$, and 14 days; Lane 6 control DFT solution in $0.5 \mathrm{M} \mathrm{NaCl}$ in phosphate buffer $(1 \mu \mathrm{g} / \mathrm{ml})$. (B) Analysis of DFT released from microspheres in $1.0 \mathrm{M} \mathrm{NaCl}$ in phosphate buffer, at various time points: Lanes 1-5: DFT in fractions collected at $8 \mathrm{hr}, 2,6,10$, and 14 days; Lane 6 control DFT solution in $1.0 \mathrm{M} \mathrm{NaCl}$ in phosphate buffer $(1 \mu \mathrm{g} / \mathrm{ml})$.

\section{CONCLUSIONS}

Suspension cross-linking procedure enabled us to produce PMs characterized by good spherical geometry, smooth surface, and relative narrow size distribution. Aminated microspheres possessing basic groups with different $\mathrm{pK}_{\mathrm{b}}$ were obtained by treatment of PMs with N,N-diethyl-N-(2-chloroethyl)amine, whereas microspheres containing only quaternary ammonium groups were produced by means of derivatization of cross-linked PMs with glycidyltrialkyl ammonium chloride. The resulting cationized microspheres were characterized by a more irregular surface with respect to the neutral PMs but no significant
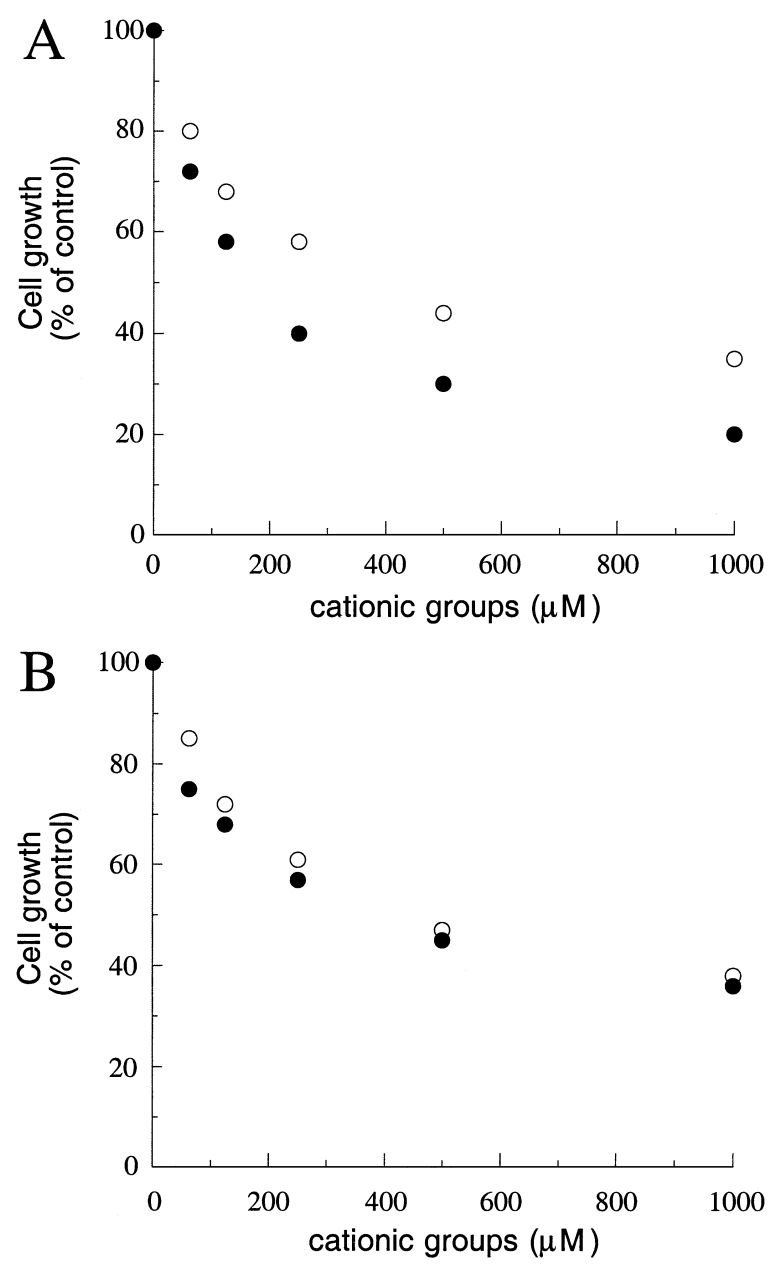

FIG. 10. In vitro cytotoxic effect of cationized polysaccharide microspheres with structure IV (A) and V (B) on human leukemic K562(S) cells. Starch microspheres-closed symbols. Pullulan microspheres-open symbols. Determinations were performed after 4 days of cell culture. Data represent the mean of three independent experiments and are expressed as percentage of cell number/ml compared with untreated control K562 cells.

changes in the particle mean diameter and morphology were observed.

All the produced cationic microspheres were able to quantitatively load DNA. The release of DNA from PMs was strongly affected by the ionic strength of the receiving fluid. In addition, at the same DNA-loading level, the release was slightly more rapid from the pullulan than from the starch microspheres. Finally agarose gel electrophoresis of DNA released from microspheres indicated that no DNA degradation occurs even after 14 days of release from PMs.

In the field of gene transfer vehicles, nonviral systems have emerged as potentially safe and effective gene vectors. Among nonviral systems, microparticles possess acceptable efficiency and very low potential toxicity. Taking into account these considerations, the obtained results suggest that PMs may be used for nonviral gene delivery. 


\section{REFERENCES}

Bjork, E., Isaksson, U., Edmon, P., Artursson, P. 1995. Starch microspheres induce pulsatile delivery of drugs and peptides across the epithelial barrier by reversible separation of the tight junctions. J. Drug Target 2:501507.

Cortesi, R., Esposito, E., Osti, M., Squarzoni, G., Menegatti, E., Davis, S. S., and Nastruzzi, C. 1999. Dextran cross-linked microspheres as drug delivery system. Eur. J. Pharm. Biopharm. 47:153-160.

Cortesi, R., Esposito, E., and Nastruzzi, C. 2000. Effect of DNA complexation and freeze-drying on the physicochemical characteristics of cationic liposomes. Antisense Nucleic Acid Drug Devel. 10:205215.

Crystal, R. G. 1995. Transfer of genes to humans: early lessons and obstacles to success. Science 270:404-410.

Curiel, D. T., Wagner, E., Cotten, M., Birnstiel, M. L., Agarwal, S., Li, C. M., Loechel, S., and Hu, P. C. 1992. High-efficiency gene transfer mediated by adenovirus coupled to DNA-polysine complexes. Hum. Gene Ther. 3:147154.

Dekie, L., Toncheva, V., Dubruel, P., Schacht, E. H., Barrett, L., and Seymour, W. 2000. Poly-L-glutamic acid derivatives as vectors for gene therapy. J. Control. Rel. 65:187-202.

Esposito, E., Sebben, S., Cortesi, R., Menegatti, E., and Nastruzzi, C. 1999. Preparation and characterization of cationic microspheres for gene delivery. Int. J. Pharm. 189:29-41.

Esposito, E., Cortesi, R., Porta, R., Trento, F., and Nastruzzi, C. 2002. Effect of long-term stabilization of DNA-liposome complexes: an in vivo study. Drug Devel. Res. 55:127-138.

Galanis, E., Vile, R., and Russell, S. J. 2002. Delivery systems intended for in vivo gene therapy of cancer: targeting and replication competent viral vectors. Crit. Rev. Oncol./Hematol. 38:177-192.

Godbey, W., Wu, K., Hirasachi, G., and Mikos, A. 1999. Improved packing of poly(ethylenimine)/DNA complexes increases transfection efficiency. Gene Ther. 6:1380-1388

Hamdi, G., Ponchel, G., and Duchene, D. 1998. An original method for studying in vitro the enzymatic degradation of cross-linked starch microspheres. J. Control. Rel. 55:193-201.

Helfferich, F. (ed.) 1962. Ion Exchange. New York: McGraw Hill.

Hug, P., and Sleight, R. G. 1991. Liposomes for the transformation of eukaryotic cells. Biochim. Biophys. Acta 1097:1-15.

Illum, L., Jørgensen, H. Bisgaard, H., Krogsgaard, O., and Rossing, N. 1987. Bioadhesive microspheres as a potential nasal drug delivery system. Int. J. Pharm. 39:189-199.

Kabanov, A. V., and Kabanov, V. A. 1995. DNA complexes with polycations for the delivery of genetic material into cells. Bioconj. Chem. 6:720 .

Kamiya, H., Tsuchiya, H., Yamazaki, J., and Harashima, H. 2001. Intracellular trafficking and transgene expression of viral and non-viral gene vectors. $A d v$. Drug Del. Rev. 52:153-164.
Lindberg, B., Lote, K., and Teder, H. 1984. Biodegradable starch-a new medical tool. In. S. S. Davis, L. Illum, J. G. McVie, and E. Tomlinson (eds.), Microspheres and Drug Therapy. Amsterdam: Elsevier, 153-188.

Leong, K. W., Mao, H. Q., Truong-Le, V. L., Roy, K., Walsh, S. M., and August, J. T. 1998. DNA-polycation nanospheres as nonviral gene delivery vehicles. J. Control. Rel. 53:183-193.

Low, P. S. 1995. Vitamin-mediated delivery of proteins, antisense oligonucleotides and gene into living cells. Restor. Neurol. Neurosci. 8:15-18.

Ogris, M., and Wagner, E. 2002. Targeting tumors with non-viral gene delivery systems. Drug Dis. Today 7:479-485.

Oku, N., Yamazaki, Y., Matsuura, M., Sugiyama, M., Hasegawa, M., and Nango, M. 2001. A novel non-viral gene transfer system, polycation liposomes. Adv. Drug Del. Rev. 52:209-218.

Pouton, C. W., Seymour, L. W. 2001. Key issues in non-viral gene delivery. $A d v$. Drug Deliv. Rev. 46:187-203.

Prokop, A. et al. 2002. Maximizing the in vivo efficiency of gene transfer by means of nonviral polymeric gene delivery vehicles. J. Pharm. Sci. 91:67-76.

Robbins, P. D., Tahara, H., and Ghivizzani, S. C. 1998. Viral vectors for gene therapy. TIBTech $16: 35-40$.

Soane, R. J., Frier, M., Perkins, A. C., Jones, N. S., Davis, S. S., and Illum, L. 1999. Evaluation of the clearance characteristics of bioadhesive systems in humans. Int. J. Pharm. 178:55-65.

Spack, E. G., Sorgi, F. L. 2001. Developing non-viral DNA delivery systems for cancer and infectious disease. Drug Discov. Today 6:186-197.

Teder, H., and Johanssan, C. J. 1993. The effect of different dosages of degradable starch microspheres (Spherex) on the distribution of doxorubicin. Anticancer Res. 13:2161-2164.

Tinsley-Bown, A. M., Fretwell, R., Dowsett, A. B., Davis, S. L., and Farrar, G. H. 2000. Formulation of poly(D,L-lactic-co-glycolic acid) microparticles for rapid plasmid DNA delivery. J. Control. Rel. 66:229-241.

Tripathy, S. K., Black, H. B., Goldwasse, E., and Leiden, J. M. 1996. Immune responses to transgene-encoded proteins, limit the stability of gene expression after injection or replication-defective adenovirus vectors. Nat. Med. 2:545550.

Truong-Le, V. L., August, J. T., and Leong, K. W. 1998. Controlled gene delivery by DNA-gelatin nanospheres. Hum. Gene Ther. 9:1709-1717.

Vaheri, A., and Pagano, J.S. 1965. Infections poliovirus RNA: a sensitive method of assay. Virology 27:434-436.

Van de Wetering, P., Cheng, J. Y., Talsma, H., Crommelin, D. J. A., and Hennink, E. W. 1998. 2-(dimethylamino)ethyl methacrylate based (co) polymers as gene transfer agents. J. Control. Rel. 53:145-153.

Van de Wetering, P., Moret, E. E., Schuurmans-Nieuwenbroek, N. M., Van Steenbergen, M. J., and Hennink, W. E. 1999. Structure-activity relationships of water-soluble cationic methacrylate/methacrylamide polymers for nonviral gene delivery. Biocon. Chem. 10:589-597.

Wilson, J. M. 2001. Adenovirus-mediated gene transfer to liver. Adv. Drug Del. Rev. 46:205-209.

Wu, N., and Ataai, M. M. 2000. Production of viral vectors for gene therapy applications. Cur. Opin. Biotech. 11:205-208. 